\title{
Seroprevalence of Hepatitis B Virus Infection and Risk Factors among Adolescents and Youth in Secondary School in 2018, Commune of Covè, Benin
}

\author{
Barikissou Georgia Damien1", Badirou Aguemon², Cyriaque Degbey ${ }^{3,4}$, Styline Agbazahou², \\ Sètondji Géraud Roméo Padonou ${ }^{2}$, Marius Edgard Ouendo ${ }^{3}$
}

${ }^{1}$ Population and Health Research Unit, Center for Training and Research for Population, University of Abomey-Calavi, Cotonou, Benin

${ }^{2}$ Department of Public Health, Faculty of Health Sciences, University of Abomey-Calavi, Cotonou, Benin

${ }^{3}$ Regional Institute of Public Health, University of Abomey-Calavi, Cotonou, Benin

${ }^{4}$ University Hospital Hygiene Clinic of National University Hospital Center Hubert Koutoukou MAGA, Cotonou, Benin

Email: ^barikiss2000@yahoo.fr

How to cite this paper: Damien, B.G., Aguemon, B., Degbey, C., Agbazahou, S., Padonou, S.G.R. and Ouendo, M.E. (2021) Seroprevalence of Hepatitis B Virus Infection and Risk Factors among Adolescents and Youth in Secondary School in 2018, Commune of Covè, Benin. Open Journal of Epidemiology, 11, 326-347.

https://doi.org/10.4236/ojepi.2021.113028

Received: June 9, 2021

Accepted: August 22, 2021

Published: August 25, 2021

Copyright $\odot 2021$ by author(s) and Scientific Research Publishing Inc. This work is licensed under the Creative Commons Attribution International License (CC BY 4.0).

http://creativecommons.org/licenses/by/4.0/

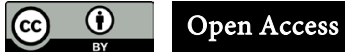

\begin{abstract}
Background: Hepatitis B is a vaccine-preventable liver infection caused by the hepatitis B virus. The study aimed to determine the prevalence and associated factors of hepatitis B infection in adolescents and youth attending secondary school in Covè, urban area in Benin. Methods: From $4^{\text {th }}$ to $10^{\text {th }}$ February 2018, a cross-sectional survey was conducted among adolescents and youth aged 15 to 24 years old. Subjects were randomly selected. Hepatitis B surface antigenaemia (HBsAg) was assayed in blood using rapid enzyme-linked immunosorbent assay kits. Univariate and multivariate analyses were performed. Results: Two hundred adolescents and youth were recruited. The seroprevalence of hepatitis B virus infection was $18.50 \%$. According to the multivariate logistic regression model, being infected by hepatitis B was 4.32 times higher in the age group of $15-19$ years old than in 20 24 years age group ( $\mathrm{PR}=4.3295 \% \mathrm{CI}[1.51-12.34], \mathrm{p}=0.0063)$. Similarly, students who had not been aware of hepatitis $\mathrm{B}$ were more infected than those who were sensitized ( $P R=14.60$ [95\% CI $4.98-4.27], \mathrm{p}=0.0001)$. With regard to lifestyle, individuals with tattoos or piercings were 8.60 times more likely to have been infected by HBV than those without tattoos or piercings, $(\mathrm{PR}=8.60 ; 95 \% \mathrm{CI}[3.41-21.70], \mathrm{p}<0.0001)$. Conclusion: The seroprevalence of hepatitis B among adolescents and youth attending secondary school was high. Regular screening of HVB infection status should be included in school health services in Benin. Awareness campaigns and health education on HVB transmission and prevention should be promoted and strengthened.
\end{abstract}




\section{Keywords}

Hepatitis B Virus, Adolescents and Youth, Benin

\section{Introduction}

Viral Hepatitis B infection (HBV) is a major global health problem and is an important cause of death worldwide [1] [2] [3]. Hepatitis B is spread when blood, semen, or other body fluids from a person infected with the virus enter the body of someone who is not infected [4]. The virus is most commonly transmitted from mother to child during birth and delivery, as well as through contact with blood or other body fluids, including sex with an infected partner, injection-drug use that involves sharing needles, syringes, or drug-preparation equipment and needle sticks or exposures to sharp instruments [1] [4]. Complications of chronic HBV infection such as chronic hepatitis, cirrhosis, and hepatocellular carcinoma [5] account for 500,000 to 1.4 million deaths yearly [3] [6]. In Sub-Saharan Africa, several studies estimated between 10\% and 15\% seroprevalence of HBV surface antigen (HBsAg) [7]. As of 2016, only 27 million people (10.5\% of all people estimated to be living with hepatitis B) were aware of their infection [8].

In Benin, the prevalence of HBV infection, cirrhosis and primary liver cancer are poorly documented in adolescents and youth but clinical reports are alarming. The prevalence of HBV is estimated from the 2013 national survey to be 9.9\%, which corresponds to about 1,000,000 people with HBV in Benin's estimated population of 10 million [9]. In 2019, seroprevalence of HBV and its associated factors were determined based on data from a screening campaign targeting the general volunteers in Benin. HBV seroprevalence was $6 \%$ and male subjects elder than 17 years old with secondary-level education were mainly affected [10]. Age, gender, geographic region, socioeconomic status, immunization status, lifestyle, sanitation and hygiene, and their relative contributions can influence the prevalence of HBV infection [11] [12]. Among the interventions carried out by Benin country, there were: 1) the introduction in 2002 of the hepatitis B vaccine, systematic and free of charge for children from 0 to 11 months of age within the framework of the Expanded Programme on Immunisation (EPI) [9], and the 2) the promulgation of law 2017-28 on the prevention, management and control of hepatitis B and C in the Republic of Benin adopted on September 14, 2017 [13]. Unfortunately, most people with chronic viral hepatitis are not aware of their status and do not receive appropriate treatment, particularly young people aged 15 to 24 [10] [12] [14]. Very recently, from October 1, 2020 , the vaccine against HBV is administered within 24 hours after birth. The majority of them were not vaccinated because they were born before the beginning of EPI intervention. The objectives of our study were therefore to determine the prevalence of HBV infection among adolescents and youth, and iden- 
tify factors associated with HBV infection.

\section{Materials and Methods}

\subsection{Study Area}

This study was conducted in the commune of Covè. The commune of Covè is located in the south-east of the Department of Zou in the south region of the Republic of Benin. It covers an area of $525 \mathrm{~km}^{2}$. The town of Covè is located between $2^{\circ} 58^{\prime}$ longitude East and $7^{\circ} 2.25^{\prime}$ latitude North. The urban agglomeration covers $55 \mathrm{~km}^{2}$ and is $157 \mathrm{~km}$ from the city of Cotonou. The commune is composed of eight arrondissements, which are in turn subdivided into 40 villages and city [15] [16]. According to the final results of the 2013 General Census of Population and Housing (RGPH4), the commune of Covè had 51,247 inhabitants, e.g. $6.0 \%$ of the Beninese population and its female population was estimated to $52.2 \%$. The proportion of people aged 15 to 24 years was the best represented in all the arrondissements (20\%) [16]. The literacy rate of young people aged 15 to 24 was $20.5 \%$. A schooling rate of adolescents and youth aged 12 to 19 was $51.1 \%$ [14]. In the commune of Covè, there were eight colleges, six public, one private and one religious. These schools are under the supervision of the Secondary School Departmental Direction. Our study took place in the six public colleges. Many public health facilities were accessible in the commune. Adolescents and Youth Sexual and Reproductive health intervention programmes were not active in the study area at the time of the study.

\subsection{Methods}

\subsubsection{Study Design}

A cross-sectional survey was carried out in February 2018 from $04^{\text {th }}$ to $10^{\text {th }}$.

\subsubsection{Study Population and Inclusion Criteria}

The adolescents and youth who met the following criteria were included in the study: 1) 15 - 24 age group and 2) had been attending one of the six public colleges for at least two years.

\subsubsection{Sampling}

Non-proportional random stratified sampling was used. A stratum corresponded to one college. Since six colleges were present, six strata were considered. The initial size of each stratum was: stratum $1=2383$ individuals, stratum $2=918$ individuals, stratum $3=986$ individuals, stratum $4=329$ individuals, stratum $5=153$ individuals and stratum $6=144$ individuals. The sample population was distributed evenly across the strata. Within each of the strata, adolescents and youth were randomly selected using a simple random sampling procedure. The list of students of each college was used for this purpose.

\subsubsection{Sample Size}

The minimum sample size was calculated by the Schwartz formula: $n=\left(\varepsilon^{\wedge} 2{ }^{\star} p\right.$ $\left.{ }^{\star} \mathrm{q}\right) / \mathrm{i}^{\wedge} 2$ considering: $\mathrm{n}$ is a minimum the sample size, $\varepsilon$ is the standard normal 
deviate ( 1.96 for $95 \%$ confidence level) and $\mathrm{i}=0.05$ is the desired precision or sampling error (tolerance error 5\%). The prevalence $\mathrm{p}$ of HBV considered was 9.9\% (from the Ministry of Health's 2013 statistics book) [17] and q is the proportion of the population that does not have the characteristic $(q=1-p)$. The required minimum sample size was $\mathrm{n}=139$ adolescents and youth.

\subsubsection{Data Collection Procedure}

Demographic and explanatory variables were collected using a structured questionnaire via face-to-face interview. The questionnaire was pretested and validated 1 two weeks before the beginning of the work and the contents found not to be ambiguous to the subjects. The questionnaire was sectionalised into socio-demographic characteristics, risk factors associated with HBV infection and vaccination history. Micropoint ${ }^{\circledast}$ rapid diagnostic tests (RDTs) were used for HBsAg detection. HBsAg-positive corresponded to the presence of HBsAg in serum and indicates that the individual has a current infection. The sensitivity and specificity of the RDT were $97.8 \%$ and $99.0 \%$ respectively and the storage temperature was $2^{\circ} \mathrm{C}-30^{\circ} \mathrm{C}$. Three trained interviewers were responsible for completing the questionnaires and the laboratory technicians were trained for taking blood samples and for testing by using RDT. Supervision was provided by HBV midwife specialist. The laboratory test results for participants were anonymously linked to their questionnaire information through unique identifiers.

\subsubsection{Study Variables}

The dependent variable is the presence or absence of HBV infection in the adolescent and youth. The independent variables were: 1) Socio-demographic variables of adolescents and youth attending school (age, sex, school level, school attended); 2) Socio-demographic variables of the parents of adolescents and youth (size of household; father's occupation; mother's occupation; father's education level); 3) Variables related to the knowledge (knowledge on hepatitis); 4) Variables related to the lifestyle or personal history (presence of tattoos and/or piercings; alcohol consumption; drug consumption; use of personal cutlery; circumcision/excision; history of blood transfusion; history of surgery; history of intravenous injection; use of personal sharp objects); 5) Sex life variables (sexual activity; multi-partnership; history of sexually transmitted infections; having unprotected sex; casual sex; anal sex; oral sex; group sex).

\subsubsection{Data Processing and Analysis}

Data analysis was carried out using EPI-INFO version 7.0 software. First, a descriptive analysis of the socio-demographic variables was carried out. In a second step, we tested the association between HBV infection and the independent variables with the Chi2 test. In the case where the theoretical numbers are less than 5 the Fisher test was considered. In the multivariate model, the association is considered significant at the $\mathrm{p}<0.05$ level. The strength of the association between HBV and the explanatory variables was expressed using prevalence ratios (PR). In the subsample of sexually active young people, we focused on the 
association between HBV infection and sexual behaviour. A univariate analysis was performed for this purpose.

\subsubsection{Ethical Considerations}

The administrative and health authorities were informed and they gave a research permit. Data collection was preceded by free, informed and consent. Before the beginning of the data collection, the enumerators visited the selected schools to familiarize themselves with the school authorities and students. During the familiarization visits, the students and teachers were given a brief talk on HBV infection and the objectives of the study were explained to the students. The selected students were given a consent form to take home to their parents and brought back the next day. The data collected were strictly confidential and anonymous. Before the survey began, a working session was held with health facility managers of the study area on the management of positive HBsAg. Reference forms were designed for this purpose and gave to the HBsAg positive participants. They were sent to the medical team for free additional exams and treatments according to the national policy.

\section{Results}

\subsection{Description of the Study Population}

\subsubsection{Prevalence of Viral Hepatitis B}

The prevalence of $\mathrm{HBV}$ was $18.50 \%$ among adolescents and youth attending secondary school in the commune of Covè.

\subsubsection{Socio-Demographic Characteristics of Adolescents and Youth}

A total of 200 adolescents and youth were included in our study, 33 in three colleges and 34 in two colleges. The average age of sampling students was $18.11 \pm 2$ years. The most represented age group was 15 to 19 years (77.50\%). Males represented $52.00 \%$ of the population sampled. The majority of the respondents were in the first level of secondary school (79.00\%).

\subsubsection{Socio-Demographic Characteristics of the Parents of Adolescents and Youth}

A total of $27.5 \%$ of the fathers of the respondents had never attended school. The majority of fathers were farmers (50.50\%), and artisans $(21.00 \%)$. Their mothers were mostly shopkeepers (53.00\%), and housewives $(26.00 \%)$ (Table 1 ).

\subsubsection{Knowledge of Viral Hepatitis B}

More than half (51\%) of the respondents had never heard of hepatitis. Of those who had heard about it, $46.0 \%$ had heard about it in a health centre, $17.5 \%$ on the radio, $15.5 \%$ on the internet, $9.0 \%$ from their parents, $7.0 \%$ from television, and $5.5 \%$ from newspapers.

\subsubsection{Lifestyle/Medical History}

The proportion of students who declared that they have used personal sharp objects was $73.5 \%$. 33.5\% said they had misused at least once and $2.5 \%$ said that 
Table 1. Socio-demographic characteristics of the parents of adolescents and youth, Covè 2018.

\begin{tabular}{|c|c|c|}
\hline Variables & $\mathbf{n}$ & $\%$ \\
\hline \multicolumn{3}{|l|}{ Father's occupation } \\
\hline Craftsman/artisan & 42 & 21.00 \\
\hline Teacher & 28 & 14.00 \\
\hline Trader & 20 & 10.00 \\
\hline Farmer & 101 & 50.50 \\
\hline Other & 9 & 4.50 \\
\hline \multicolumn{3}{|c|}{ Father's education level } \\
\hline No schooling & 55 & 27.50 \\
\hline Primary & 48 & 24.00 \\
\hline Secondary & 90 & 45.00 \\
\hline Higher & 7 & 3.50 \\
\hline \multicolumn{3}{|l|}{ Mother's occupation } \\
\hline Craftsman/artisan & 18 & 9.0 \\
\hline Teacher & 6 & 3.0 \\
\hline Trader & 106 & 53.0 \\
\hline Farmer & 18 & 9.0 \\
\hline Housekeeper & 52 & 26.0 \\
\hline \multicolumn{3}{|l|}{ Household's size } \\
\hline $1-4$ & 55 & 27.5 \\
\hline $5-8$ & 82 & 41.0 \\
\hline $9-12$ & 63 & 31.5 \\
\hline
\end{tabular}

they had used recreational drugs at least once in their life. Only $45.5 \%$ of the participants said that they regularly used personal cutlery for meals.

$20.5 \%$ had a tattoo or piercing. Also $18 \%$ and $4.5 \%$ respectively benefit from blood transfusions and surgical interventions at least once. All the males in the sample $(n=104)$ had been circumcised and only one of the girls $(n=96)$ in our survey had been circumcised. The majority of students received an intravenous injection at least once (75.5\%).

\subsubsection{Sexual Behaviour}

A large proportion of students were sexually active (61.00\%). The proportion of them who had an STI at least once was $10 \%$, and only gonococcal and vaginal candidiasis infection was cited.

Among the 122 sexually active individuals, $31.10 \%$ declared to have had their first sexual intercourse between 10 and 15 years old and $68.85 \%$ between 16 and 24 years old.

In the group of sexually active subjects, $20.5 \%$ had more than one sexual 
partner during the twelve months preceding the study. Of those who had at least one sexual partner during the period of the study, 55.29\% have unprotected sex. Some of the students practised anal sex, oral sex and group sex: $4.09 \%, 24.6 \%$ and $0.9 \%$ respectively (Table 2 ).

\subsubsection{Vaccination}

Only six individuals had been vaccinated against HBV infection. Of those, three of them received a single dose, two of them received two doses and one received three doses.

Table 2. Adolescents and youth according to factors related to sexual behaviour, Covè, 2018.

\begin{tabular}{|c|c|c|}
\hline Variables & $\mathbf{n}$ & $\%$ \\
\hline \multicolumn{3}{|c|}{ Age at first sexual intercourse (years) } \\
\hline $10-15$ & 38 & 31.15 \\
\hline $16-24$ & 84 & 68.85 \\
\hline \multicolumn{3}{|c|}{ Number of partners in the last 12 months } \\
\hline One partner & 39 & 32.00 \\
\hline Two partners & 58 & 47.50 \\
\hline More than one partner & 25 & 20.50 \\
\hline \multicolumn{3}{|l|}{ Current partner } \\
\hline Yes & 85 & 69.67 \\
\hline No & 37 & 30.33 \\
\hline \multicolumn{3}{|l|}{ Having protective sex } \\
\hline Yes & 38 & 44.71 \\
\hline No & 47 & 55.29 \\
\hline \multicolumn{3}{|c|}{ Occasional sexual intercourse } \\
\hline Yes & 25 & 20.49 \\
\hline No & 97 & 79.51 \\
\hline \multicolumn{3}{|l|}{ Anal sex } \\
\hline Yes & 5 & 4.10 \\
\hline No & 117 & 95.90 \\
\hline \multicolumn{3}{|l|}{ Oral sex } \\
\hline Yes & 30 & 24.60 \\
\hline No & 92 & 75.40 \\
\hline \multicolumn{3}{|l|}{ Group sex } \\
\hline Yes & 1 & 0.90 \\
\hline No & 121 & 99.10 \\
\hline
\end{tabular}

STIs: Sexually transmitted infections. 


\subsection{Factors Associated with Viral Hepatitis B Infection in Adolescents and Youth}

\subsubsection{Association between Viral Hepatitis B Infection and Socio-Demographic Characteristics of Adolescents and Youth Attending School, Univariate Analysis}

In the univariate analysis, only age variable was significantly linked to HBV infection prevalence. The proportion of infection was 1.87 times higher in $15-19$ years old than in $20-24$ years old $(\mathrm{RP}=1.87 ; 95 \%$ CI $[1.03-3.35]$ and $\mathrm{p}=$ 0.0400) (Table 3).

In univariate analysis, parental socio-demographic characteristics were not associated with HBV infection in adolescents and youth.

\subsubsection{Association between Viral Hepatitis B Infection and the Level of Knowledge, Univariate Analysis}

The level of knowledge was significantly associated with the prevalence of HBV infection ( $p$-value $=0.0002$ ). Individuals who had received no information about HBV were 3.48 times more likely to be infected with HBV than those who had received information $(\mathrm{PR}=3.48$; 95\% CI $[1.67-7.24]$ ) (Table 4).

\subsubsection{Association between Hepatitis B Infection and Lifestyle of Adolescents and Young People, Univariate Analysis}

Adolescents or youth who had tattoos and/or piercings had a four times higher prevalence of hepatitis B compared to those without tattoos or piercings ( $\mathrm{p}<$ 0.0001 and $\mathrm{PR}=4.09 ; 95 \% \mathrm{CI}[2.37-7.06])$. Adolescents or youth with a history of blood transfusion had a two times higher proportion of being infected compared to those without blood transfusions $\mathrm{p}=0.0410$ (Table 4).

\subsubsection{Association between Viral Hepatitis B Infection and Sexual Behaviour, Univariate Analysis}

In the target group of sexually active students ( $61.00 \%$ of the sample), individuals who had their first sexual intercourse between 10 and 15 years old were 3.43 times more likely to have HBV infection than those who had their first sexual intercourse between 16 and 24 years old $(\mathrm{p}=0.0006, \mathrm{RP}=3.43$; 95\% CI [1.63 7.24]).

Similarly, individuals who had no sexual partner during 12 months prior to the study were 8.70 times less likely to have HBV infection than individuals who had more than one partner during this period $(\mathrm{p}=0.0100$ and $\mathrm{PR}=8.70 ; 95 \% \mathrm{CI}$ [1.67 - 45.44])

Protection during sexual intercourse was also related to HBV infection ( $\mathrm{p}=$ 0.0020 and $\mathrm{PR}=6.00,95 \%$ CI $[1.47-24.88]$ ). Individuals who did not use a condom during sex were 6 times more likely to have HBV infection than those who used protection.

The occurrence of casual sex increased the occurrence of HBV infection ( $\mathrm{p}<$ 0.0001 with $\mathrm{RP}=18.43$; 95\% CI [6.88 - 49.32]).

Finally, those who had group sex were 5.5 times more likely to have hepatitis $\mathrm{B}$ than those who did not $(\mathrm{PR}=5.50 ; 95 \% \mathrm{CI}[3.76-8.02])$ and $\mathrm{p}=0.0300$ (Table 5). 
Table 3. Association between hepatitis B virus infection and socio-demographic characteristics of adolescents and youth, univariate and multivariate analysis, Covè, 2018.

\begin{tabular}{|c|c|c|c|c|c|c|}
\hline \multicolumn{7}{|c|}{ Hepatitis B virus infection } \\
\hline Variables & Positive n (\%) & Negative $\mathrm{n}(\%)$ & Crude PR & p-value & Adjusted PR & p-value \\
\hline \multicolumn{7}{|l|}{ Age group (years) } \\
\hline $15-19$ & $24(12.00)$ & $131(65.50)$ & $1.87[1.03-3.35]$ & $0.0400^{\star}$ & $4.32[1.51-12.34]$ & $0.0063^{*}$ \\
\hline $20-24$ & $13(6.50)$ & $32(16.00)$ & 1 & & 1 & \\
\hline \multicolumn{7}{|l|}{ Sex } \\
\hline Male & $17(8.50)$ & $87(43.50)$ & 1 & & & \\
\hline Female & $20(10.00)$ & $76(38.00)$ & $0.78[0.44-1.40]$ & 0.4100 & & \\
\hline \multicolumn{7}{|l|}{ Education's level } \\
\hline 1er cycle & $26(13.00)$ & $132(66.00)$ & 1 & & & \\
\hline 2nd cycle & $11(5.50)$ & $31(15.50)$ & $0.63[0.34-1.16]$ & 0.1500 & & \\
\hline \multicolumn{7}{|l|}{ Stratum (school) } \\
\hline College 1 & $6(3.00)$ & $28(14.00)$ & 1 & & & \\
\hline College 2 & $9(4.50)$ & $25(12.50)$ & $1.68[0.52-5.39]$ & 0.3800 & & \\
\hline College 3 & $10(5.00)$ & $23(11.50)$ & $2.03[0.64-6.42]$ & 0.2300 & & \\
\hline College 4 & $4(2.00)$ & $29(14.50)$ & $0.64[0.16-2.53]$ & 0.5300 & & \\
\hline College 5 & $5(2.50)$ & $28(14.00)$ & $0.83[0.23-3.05]$ & 0.7800 & & \\
\hline CEG 6 & $3(1.50)$ & $30(15.00)$ & $0.47[0.11-2.05]$ & 0.3100 & & \\
\hline \multicolumn{7}{|l|}{ Father's occupation } \\
\hline Craftsman/artisan & $8(4.00)$ & $34(17.00)$ & 1 & & & \\
\hline Teacher & $7(3.50)$ & $21(10.50)$ & $1.41[0.45-4.48]$ & 0.5500 & & \\
\hline Trader & $4(2.00)$ & $16(8.00)$ & $1.06[0.28-4.05]$ & 0.9300 & & \\
\hline Farmer & $18(9.00)$ & $83(41.50)$ & $0.92[0.37-2.32]$ & 0.8600 & & \\
\hline Other & $0(0.00)$ & $9(4.50)$ & - & 0.9700 & & \\
\hline \multicolumn{7}{|l|}{ Father's education } \\
\hline No schooling & $15(7.50)$ & $40(20.00)$ & 1 & & & \\
\hline Primary & $7(3.50)$ & $41(20.50)$ & $0.45[0.17-1.23]$ & 0.1200 & & \\
\hline Secondary & $14(7.00)$ & $76(38.00)$ & $0.49[0.21-1.11]$ & 0.0900 & & \\
\hline Higher & $1(0.50)$ & $6(3.00)$ & $0.44[0.05-4.00]$ & 0.4700 & & \\
\hline \multicolumn{7}{|l|}{ Mother's occupation } \\
\hline Craftsman/artisan & $2(1.00)$ & $16(8.00)$ & 1 & & & \\
\hline Teacher & $1(0.50)$ & $5(2.50)$ & $1.60[0.12-21.58]$ & 0.72 & & \\
\hline Trader & $18(9.00)$ & $88(44.00)$ & $1.64[0.34-7.75]$ & 0.53 & & \\
\hline Farmer & $3(1.50)$ & $15(7.50)$ & $1.60[0.23-10.94]$ & 0.63 & & \\
\hline Housekeeper & $13(6.50)$ & $39(19.50)$ & $2.67[0.54-13.18]$ & 0.23 & & \\
\hline \multicolumn{7}{|l|}{ Household's size } \\
\hline $1-4$ & $12(6.00)$ & $43(21.50)$ & 1 & & & \\
\hline $5-8$ & $17(8.50)$ & $65(32.50)$ & $0.94[0.41-2.16]$ & 0.8800 & & \\
\hline $9-12$ & $8(4.00)$ & $55(27.50)$ & $0.52[0.19-1.39]$ & 0.1900 & & \\
\hline
\end{tabular}

${ }^{*}$ Association is statistically significant; PR: prevalence ratio. 
Table 4. Association between hepatitis B virus infection and level of knowledge of adolescents' and youth, univariate and multivariate analysis, Covè, 2018.

\begin{tabular}{|c|c|c|c|c|c|c|}
\hline \multicolumn{7}{|c|}{ Hepatitis B virus infection } \\
\hline Variables & Positive n (\%) & Negative n (\%) & Crude PR & p-value & Adjusted PR & p-value \\
\hline \multicolumn{7}{|c|}{ Be aware on hepatitis $B$} \\
\hline Yes & $29(14.50)$ & $90(45.00)$ & 1 & & 1 & \\
\hline No & $8(4.00)$ & $73(36.50)$ & $3.48[1.67-7.24]$ & $0.0002^{*}$ & $14.60[4.98-4.27]$ & $0.0001^{\star}$ \\
\hline \multicolumn{7}{|c|}{ Piercing/Tattoos } \\
\hline Yes & $19(9.50)$ & $22(11.00)$ & $4.09[2.37-7.06]$ & & 1 & 1 \\
\hline No & $18(9.00)$ & $141(70.50)$ & 1 & $<0.0001^{*}$ & $8.60[3.41-21.70]$ & $<0.0001^{\star}$ \\
\hline \multicolumn{7}{|c|}{ Blood transfusion } \\
\hline Yes & $6(3.00)$ & $10(5.00)$ & $2.22[1.09-4.52]$ & $0.0410^{*}$ & & \\
\hline No & $31(15.50)$ & $153(76.50)$ & 1 & & & \\
\hline \multicolumn{7}{|c|}{ Use of non-personal sharps } \\
\hline Yes & $27(13.50)$ & $120(60.00)$ & 1 & & & \\
\hline No & $10(5.00)$ & $43(21.50)$ & $0.97[0.50-1.87]$ & 0.9300 & & \\
\hline \multicolumn{7}{|c|}{ Alcohol misuse } \\
\hline Yes & $17(8.50)$ & $50(25.00)$ & 1 & & & \\
\hline No & $20(10.00)$ & $113(56.50)$ & $1.69[0.953 .00]$ & 0.0700 & & \\
\hline \multicolumn{7}{|c|}{ Use of personal cutlery } \\
\hline Yes & $19(9.50)$ & $72(36.00)$ & 1 & & & \\
\hline No & $18(9.00)$ & $21(10.50)$ & $1.26[0.71-2.26]$ & 0.4300 & & \\
\hline \multicolumn{7}{|c|}{ Sexual activities } \\
\hline Yes & $23(11.50)$ & $99(49.50)$ & 1 & & & \\
\hline No & $14(7.00)$ & $64(32.00)$ & $1.05[0.58-1.91]$ & 0.4400 & & \\
\hline
\end{tabular}

${ }^{*}$ Association is statistically significant; PR: prevalence ratio.

Table 5. Association between hepatitis B virus infection and adolescents' and youth sexual behaviour, univariate analysis, Covè, 2018.

\begin{tabular}{|c|c|c|c|c|}
\hline \multicolumn{5}{|c|}{ Hepatitis B virus infection } \\
\hline Variables & Positive $\mathbf{n}(\%)$ & Negative $\mathbf{n}(\%)$ & Crude PR & $\mathrm{p}$-value \\
\hline \multicolumn{5}{|c|}{ Age at first sexual intercourse (years) } \\
\hline $10-15$ & $14(11.47)$ & $24(19.67)$ & 1 & \\
\hline $16-24$ & $9(7.39)$ & $75(61.47)$ & $3.43[1.63-7.24]$ & $0.0006^{*}$ \\
\hline \multicolumn{5}{|c|}{ Number of partners in the last 12 months } \\
\hline One partner & $2(1.64)$ & $37(30.33)$ & 1 & \\
\hline Two partners & $13(10.65)$ & $45(36.88)$ & $5.34[1.13-25.20]$ & $0.0300^{*}$ \\
\hline More than one partner & $8(6.56)$ & $17(13.93)$ & $8.70[1.67-45.44]$ & $0.0100^{*}$ \\
\hline
\end{tabular}




\section{Continued}

\section{Current partner}

Yes

No

Having protective sex

Yes

No

$2(2.35)$

$14(16.47)$

$19(15.57)$

$3(2.46)$

$1(0.81)$

$22(18.03)$

$7(5.74)$

$16(13.11)$

$1(0.81)$

$22(18.03)$

Group sex

Yes

No
$68(55.74)$

$31(25.41)$

$1.23[0.52-2.87]$

0.6200

$36(42.35)$

$32(37.65)$

$6.00[1.47-24.88]$

$0.0020^{*}$

$6(4.91)$

$93(76.22)$

$18.43[6.88-49.32]$

$<0.0001^{\star}$

4 (3.27)

95 (77.87)

$1.06[0.11-10.13]$

0.9400

$23(18.85)$

$76(62.29)$

$1.29[0.59-2.84]$

0.5200

$0(0)$

1

$99(81.14)$

$5.50[3.76-8.02]$

$0.0300^{*}$

${ }^{*}$ Association is statistically significant; PR: prevalence ratio.

\subsubsection{Factors Associated with Hepatitis B Infection, Multivariate} Analysis

According to the multivariate logistic regression model, the risk of being infected by hepatitis B was 4.32 times higher in 15 - 19 years old than in $20-24$ years old $(\mathrm{PR}=4.32 \mathrm{CI}=95 \%[1.51-12.34])$. Similarly, individuals who had been aware of hepatitis were less infected than those who never been sensitized $(\mathrm{PR}=14.60$ [95\% CI 4.98 - 4.27]). With regard to lifestyle, individuals with tattoos or piercings were 8.60 times more likely to have been infected by HBV than those without tattoos or piercings, $\mathrm{p}<0.0001$ ( $\mathrm{PR}=8.60$; 95\% CI $[3.41-21.70])$ (Table 3 and Table 4).

\section{Discussion}

The study aimed to determine the prevalence of HBV infection and associated factors in the adolescent and youth attending school in the commune of Covè. The seroprevalence of HBV was high at $18.5 \%$. The factors significantly associated with HBV were age, level of knowledge and the presence of tattoos or piercings. In the subgroup of sexually active adolescents and youth, age at first sexual intercourse, number of partners, having unprotected sex, casual sex and group sex were significantly associated with the prevalence of HBV infection. 


\subsection{Prevalence of Viral Hepatitis B Infection in Adolescents and Youth}

None of the participants who were tested positive for HBV infection were aware of their status. This is a concern and raises the issue of low screening for HBV infection in the adolescent and youth in Benin. This high rate may be explained by the fact that most of the young people included in the survey were born before the introduction of the HBV vaccine on the EPI intervention, or did not have access to this vaccination due to lack of information or parental neglect. Similar results were found in Côte d'Ivoire in 2013, the prevalence of HBsAg was estimated between $14 \%$ and $15 \%$ in the age group of $12-28$ years old [18].

Although HBV control strategies are comparable in Nigeria [e.g. introduction of HBV vaccination in the EPI program in 2004), the prevalence of disease was lower among young people in Enugu (3.1\%) according to Eke study's in 2015 [19].

\subsection{Factors Associated with Viral Hepatitis B Virus Infection}

In this study, we had no information on the serological status of mothers, but in Benin, since 2002, HBV vaccine has been administered to infants from 6 weeks of age [9] as part of EPI intervention and therefore probably the majority of the students included in the study were not vaccinated in childhood and neither were their parents. The risk of mother-child contamination is therefore not negligible.

\subsection{Age and Level of Knowledge}

Age was significantly linked to the prevalence of HBV infection. HBV infection was 4.32 times higher in 15 - 19 years old than in 20 - 24 years old. In addition, we found that for $1 / 3$ of the respondents, the first sexual intercourse occurred before the age of 16 years old and this was associated with a high proportion of HBV infection. A contrarily, a study conducted among children and adolescents ( 0 - 18 years old) in Nigeria showed that positivity of HBsAg was not linked to age group even if high prevalence was observed among older age group [20].

This high prevalence was probably due to the lack of experience and the lack of awareness among the youngest students regarding their lifestyle and sexual behaviour (e.g. having unprotected sex) [21]. These results mean that the pre and early adolescence age are the best age to focus on to prevent HBV by increasing knowledge and awareness to HBV and changing beliefs/attitudes and cultural norms that facilitate transmission of the disease [20].

$48 \%$ of the students declared that they have heard about HBV infection. This contrasts with a lower actual knowledge on HBV mode of transmission and prevention, indicating a superficial and insufficient knowledge of the disease. The proportion of students aware of HBV in the current study was lower than in the Thaver's et al., [22] study in Pakistan, where $98 \%$ of students declared to have heard of HBV infection. Similarly, in the study conducted by Lohouès-Kouacou et al., in Côte d'Ivoire [18], 76.6\% had received the information. In the latter study, 
the school represented $20 \%$ of the sources of information, contrary to the current study, none of the students mentioned the school as a source of information on hepatitis. The school is therefore very little involved in teaching about STI and risky sexual behaviour in the study area.

We found that vaccination declaration was not related to HBV infection, probably because of the small number of students who received the vaccine. Nevertheless, there is evidence that the HBV vaccine is key to the prevention of this disease [14] [23]. The WHO recommends that all infants should receive the vaccine as soon as possible after birth, and preferably within 24 hours. The adolescents and youth should be vaccinated to by free.

All adolescents and youth attending school or not should be vaccinated through a free vaccination programme.

\subsection{History of Tattoos and Piercings}

Having tattoos and piercings was a major risk factor for HBV. The same results were found by Eke [19] and colleagues among Nigerian adolescents. In addition to tattoos and piercings, circumcision and surgical history were also found as factors significantly related to hepatitis B [24] [25] [26] [27]. These results suggested that the transmission of HBV by sharp objects remains a major means of transmission. In order to protect the health of the youngest, the communication towards adolescents and young people and their parents or guardians for the single use of sharp objects remain topical.

\section{Limitation of the Study}

Biases related to cross-sectional and questionnaire studies must be considered for this study. In addition, only the results of RDT were taken into account in this work. The HBV status of the parents of the participants was unknown.

\section{Conclusions}

The prevalence of HBV among adolescents and youth attending school in the commune of Covè was very high. The risk factors identified were: age, knowledge of adolescents and youth, having tattoos and piercings, age at first sexual intercourse, multiple sexual partnerships, occasional sex and group sex.

There is an urgent need to strengthen prevention strategies against HBV in Benin, in particular universal vaccination and targeted behaviour change communication to adolescents and youth.

\section{Authors' Contributions}

GD, and BA designed and conceived the study, SA collected the data. GD and SA performed analysis and interpretation of the data. GD drafted the first version of the manuscript. BA, CD, SGRP and ED critically reviewed the manuscript. All authors gave their final approval to the manuscript to be published. All authors agreed to be accountable for all aspects of the work. 


\section{Funding}

Funding received from the Department of Public Health, Faculty of Health Sciences.

\section{Conflicts of Interest}

The authors declare that they have no competing interests.

\section{References}

[1] World Health Organization (2016) Global Health Sector Strategy on viral Hepatitis 2016-2021. Towards Ending Viral Hepatitis. WHO Press, Geneva, 56 p. http://apps.who.int/iris/bitstream/handle/10665/246177/WHO-HIV-2016.06-eng.p df;jsessionid=BA711DDC32EC6E6E4CB4F9D786CF303A? sequence $=1$

[2] Musa, B.M., Bussell, S., Borodo, M.M., Samaila, A.A. and Femi, O.L. (2015) Prevalence of Hepatitis B Virus Infection in Nigeria, 2000-2013: A Systematic Review and Meta-Analysis. Nigerian Journal of Clinical Practice, 18, 163-172. https://doi.org/10.4103/1119-3077.151035

[3] Shepard, C.W., Simard, E.P., Finelli, L., Fiore, A.E. and Bell, B.P. (2006) Hepatitis B Virus Infection: Epidemiology and Vaccination. Epidemiologic Reviews, 28, 112-125. https://doi.org/10.1093/epirev/mxj009

[4] Centers for Disease Control and Prevention (CDC) (2020) Division of Viral Hepatitis 2025 Strategic Plan, CDC. https://www.cdc.gov/hepatitis/pdfs/DVH-StrategicPlan2020-2025.pdf

[5] Perz, J.F., Armstrong, G.L., Farrington, L.A., Hutin, Y.J.F. and Bell, B.P. (2006) The Contributions of Hepatitis B Virus and Hepatitis C Virus Infections to Cirrhosis and Primary Liver Cancer Worldwide. Journal of Hepatology, 45, 529-538. https://doi.org/10.1016/j.jhep.2006.05.013

[6] Alexander, J. and Kowdley, K.V. (2006) Epidemiology of Hepatitis B-Clinical Implications. Medscape General Medicine, 8, Article No. 13.

[7] Bossali, F., Ndziessi, G., Ahoui-Apendi, C.L.,Deby, G., Mimiesse, M.J.F., Ombila, J.W., et al. (2018) Evaluation of Viral Hepatitis B Treatment in Pointe-Noire in 2016. International Journal of Clinical Medicine, 9, 513-519. https://doi.org/10.4236/ijcm.2018.96044

[8] World Health Organization (2016) Hepatitis B. World Health Organization, Geneva. https://www.who.int/news-room/fact-sheets/detail/hepatitis-b

[9] Kodjoh, N. (2015) Fighting Viral Hepatitis B and C in Africa Focus on Benin. Médecine et Santé Tropicales, 25, 141-144. https://doi.org/10.1684/mst.2015.0439

[10] Kpossou, A.R., Paraiso, M.N., Sokpon, C.N., Alassan, K.S., Vignon, R.K., Keke, R.K., et al. (2020) Seroprevalence of Viral Hepatitis B and Its Associated Factors Determined Based on Data from a Screening Campaign Targeting the General Population in Benin. Pan African Medical Journal, 37, Article No. 247. https://doi.org/10.11604/pamj.2020.37.247.26070

[11] Apidechkul, T. (2019) Seroprevalence and Factors Associated with Hepatitis b virus Infection among the Hill Tribe Youths, Northern Thailand. BMC Infectious Diseases, 19, Article No. 125. https://doi.org/10.1186/s12879-019-3747-3

[12] Chioma Paulina, O., Christian Chukwukere, O., Anthony Nnaemeka, I., Tochukwu Chukwukadibia, E., Emeka Charles, N., Franklin Chime, E., et al. (2021) Risk Factors, Seroprevalence and Infectivity of Hepatitis B Virus amongst Children Resident 
in Orphanages in a Developing Country. Journal of Infectious Diseases and Epidemiology, 7, 186. https://doi.org/10.23937/2474-3658/1510186

https://www.clinmedjournals.org/articles/jide/journal-of-infectious-diseases-and-ep idemiology-jide-7-186.php?jid=jide

[13] Republique du Bénin (2017) Loi 2017-28 portant prévention, prise en charge et contrôle des hépatites $\mathrm{B}$ et $\mathrm{C}$ en république du Bénin.

[14] World Health Organization (2017) Prevention, Care and Treatment of Viral Hepatitis in the African Region: Framework for Action, 2016-2020. World Health Organization; Geneva. Licence: CC BY-NC-SA 3.0 IGO.

[15] Institut National de la Statistique et de l'Analyse Économique (INSAE) (2013) Enquête Démographique et de Santé (EDSB-IV) 2011-2012. Ministère du Développement, de l'Analyse Économique et de la Prospective Cotonou, Bénin.

[16] Afrique Conseil (2013) Monographie de la commune de Covè.

[17] Ministère de la Santé (2014) Secrétariat Général du Ministère. Direction de la Programmation et de la Prospective. Annuaire des statistiques sanitaires 2013. Ministère de la Santé, Bénin.

http://www.sante.gouv.bj/documents/Annuaire_2013.pdf

[18] Lohouès-Kouacou, M.-J., Assi, C., Ouattara, A., Gohean Bonao, S., Koné, S., Soro, D., et al. (2013) Connaissance de l'hépatite virale B par les élèves des écoles secondaires en Côte d'Ivoire. Santé Publique, 25, 227-232.

https://doi.org/10.3917/spub.132.0227

[19] Eke, C.B., Ogbodo, S.O., Ukoha, O.M., Ibekwe, R.C., Asinobi, I.N., Ikuna, A.N., et al. (2015) Seroprevalence and Risk Factors of Hepatitis B Virus Infection among Adolescents in Enugu, Nigeria. Journal of Tropical Pediatrics, 61, 407-413. https://doi.org/10.1093/tropej/fmv035

[20] Villar, L.M., Amado, L.A., de Almeida, A.J., de Paula, V.S., Lewis-Ximenez, L.L. and Lampe, E. (2014) Low Prevalence of Hepatitis B and C Virus Markers among Children and Adolescents. BioMed Research International, 2014, Article ID: 324638. https://doi.org/10.1155/2014/324638

[21] Khan, F., Shams, S., Qureshi, I.D., Israr, M., Khan, H., Sarwar, M.T., et al. (2011) Hepatitis B virus infection among different sex and age groups in Pakistani Punjab. Virology Journal, 8, Article No. 225. https://doi.org/10.1186/1743-422X-8-225

[22] Thaver, A.M. and Kamal, A. (2010) Impact of Information Sources on the Knowledge of Adolescents about Hepatitis B. Journal of the Pakistan Medical Association, 60, 1072-1075.

[23] World Health Organization (2017) Hépatite B-Aide-Mémoire-N²04. World Health Organization, Geneva.

[24] Sadoh, A. Sadoh, W., Iduoriyekemwen, N. (2011) HIV Co-Infection with Hepatitis $\mathrm{B}$ and $\mathrm{C}$ Viruses among Nigerian Children in an Antiretroviral Treatment Programme. South African Journal of Child Health, 5, 7-10.

https://www.ajol.info/index.php/sajchh/article/view/69998

[25] Nwokediuko, S. (2009) Risk Factors for Hepatitis B Virus Transmission in Nigerians: A Case Control Study. The Internet Journal of Gastroenterology, 10, Article No. 1.

[26] Telatela, S.P., Matee, M.I. and Munubhi, E.K. (2007) Seroprevalence of Hepatitis B and C Viral Co-Infections among Children Infected with Human Immunodeficiency Virus Attending the Paediatric HIV Care and Treatment Center at Muhimbili National Hospital in Dar-es-Salaam, Tanzania. BMC Public Health, 7, Article No. 338.

https://doi.org/10.1186/1471-2458-7-338 
[27] Muro, F.J., Fiorillo, S.P., Sakasaka, P., Odhiambo, C., Reddy, E.A., Cunningham, C.K., et al. (2013) Seroprevalence of Hepatitis B and C Viruses among Children in Kilimanjaro Region, Tanzania. Journal of the Pediatric Infectious Diseases Society, 2, 320-326. https://doi.org/10.1093/jpids/pit018 


\section{Questionnaire}

\section{1) GENERAL INFORMATION}

Please give us your general information.

Number

[__ ] _ _ ] _ _ ]

Gender

Male $=1$

Female $=2$

[__]

Please how old are you?

$15-19$ years $=1$

$20-24$ years $=2$

[_]

Household size

$1-4=1$

$5-8=2$

$9-12=3$

[_]

Father's occupation

Artisan $=1$

Teacher $=2$

Trader $=3$

Cultivator $=4$

Other $($ Specify $)=5$

[_]

Mother's occupation

Artisan $=1$

Teacher $=2$

Trader $=3$

Cultivator $=4$

Household $=5$

Other $($ Specify $)=6$

[_]

Level of education

Not in school $=1$

Primary $=2$

Secondary $=3$

Superior $=4$

[_]

Class

1 st cycle $=1$

2nd cycle $=2$

[_] 


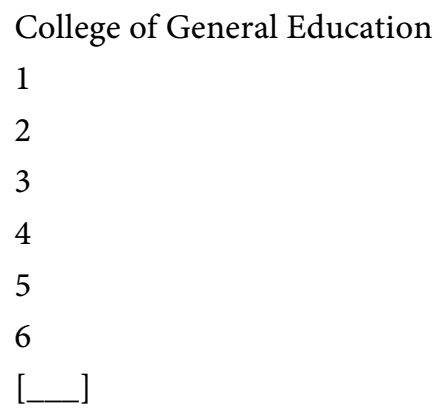

\section{2) LIFE}

Now you would like to give us some information about your lifestyle Have you ever had tattoos or piercings?

Yes $=1$

No $=2$

[_]

Have you had a blood transfusion at least once?

Yes $=1$

$\mathrm{No}=2$

[_]

If it is a man. Have you been circumcised?

Yes $=1$

No $=2$

[]

If it is a woman. Have you been circumcised?

Yes $=1$

No $=2$

[_]

Have you had surgery at least once in your life?

Yes $=1$

$\mathrm{No}=2$

[_]

Have you ever had an intravenous injection?

Yes $=1$

$\mathrm{No}=2$

[_]

Do you use non-personal sharp objects?

Yes $=1$

$\mathrm{No}=2$

In the past 12 months, have you ever drunk to the point of intoxication?

Yes $=1$

No $=2$

[_]

Have you ever used drugs in your life?

Yes $=1$ 
No $=2$

[_]

If so, which ones?

NB: Do not suggest

Cannabis $=1$

Indian hemp $=2$

Cocaine $=3$

Marijuana $=4$

Other $=5$

[_]

Do you use your own cutlery (spoon, fork etc.) for your meals?

Yes $=1$

No $=2$

[_]

\section{3) SEX LIFE}

These will be matters of your privacy. Can we go there?

Have you had sex at least once in your life?

Yes $=1$

No $=2$

[_]

If yes to Q019?

How old were you when you first had sex?

$10-15=1$

$16-18=2$

$18-24=3$

[_]

If yes to Q019?

Have you ever had more than one sexual partner at a time in your life?

Yes $=1$

No $=2$

[_]

In your lifetime, have you had a sexually transmitted infection?

Yes $=1$

No $=2$

[__

If yes to Q022?

Which ones?

NB: Do not suggest

Gonorrhoea $($ discharge $)=1$

Chlamydia (Malodorous discharge) $=2$

Genital herpes (pimples on the sex) $=3$

Syphilis (sores on the sex) $=4$

Papillomavirus (fungus) $=5$

$\mathrm{HIV}=6$ 
Hepatitis $B=7$

Hepatitis $\mathrm{C}=8$

[_]

In the last 12 months, have you had one or more sexual partners?

None $=1$

One $=2$

$+1=3$

[_]

If yes to Q024?

Have you used condoms with your sexual partners in the last 12 months?

Yes $=1$

$\mathrm{No}=2$

[_]

Do you currently have a sexual partner?

Yes $=1$

No $=2$

[_]

If yes to Q026?

Do you use condoms with this partner?

Always $=1$

Often $=2$

Rarely $=3$

Never $=4$

[_]

Have you had casual sex (past or recent)?

Yes $=1$

$\mathrm{No}=2$

[_]

If yes to Q028?

Did you use a condom?

Yes $=1$

$\mathrm{No}=2$

[_]

Do you practice anal sex?

Yes $=1$

No $=2$

[_]

Do you have oral sex?

Yes $=1$

$\mathrm{No}=2$

[_]

Do you have group sex?

Yes $=1$ 
No $=2$

[_]

\section{4) KNOWLEDGE ABOUT HEPATITIS}

Thank you for your patience. We are almost at the end of our questionnaire. Now we will ask you some questions about hepatitis

Have you heard of hepatitis at least once?

Yes $=1$

$\mathrm{No}=2$

[_]

If yes to Q033?

Through which channel?

Health centres $=1$

Radio $=2$

$\mathrm{TV}=3$

Internet $=4$

Newspapers $=5$

Other $=6$

[_]

If yes to Q033?

What information did you receive?

NB: Do not suggest

Type $=1$

Transmission channels $=2$

Clinical signs $=3$

Complications $=4$

Treatment $=5$

Prevention $=6$

[_]

What types of hepatitis are you familiar with?

Hepatitis $\mathrm{A}=1$

Hepatitis $B=2$

Hepatitis $\mathrm{C}=3$

Hepatitis $\mathrm{D}=4$

Alcoholic hepatitis $=5$

Drug-induced hepatitis $=6$

Other $=7$

[__

What are the routes of transmission of viral hepatitis that you know about? Sanguine $=1$

Sexual $=2$

Mother and child = 3

Other $=4$ 
What clinical signs of hepatitis are you aware of?

NB: Do not suggest

Icterus $=1$

Fatigue $=2$

Nausea/Vomiting $=3$

Flu-like syndrome $=4$

Other $=5$

[_] ]

What are the complications that can arise?

NB: Do not suggest

Cirrhosis $=1$

Liver cancer $=2$

Kidney damage $=3$

Deaths $=4$

Other $=5$

[__]

How can hepatitis be prevented?

NB: Do not suggest

Hygiene rules $=1$

Vaccination $=2$

Other $=3$

Have you been vaccinated at least once for hepatitis B?

Yes $=1$

No $=2$

[_]

If yes to Q041?

How many doses?

1

2

3

4

5

[]

5) TEST RESULT

Hepatitis B test

Positive $=1$

Negative $=2$

[__]

Hepatitis C test

Positive $=1$

Negative $=2$ 